\title{
Clinton picks NSF chief as science adviser
}

[PHILADELPHIA] Neal Lane, the director of the National Science Foundation (NSF), is to succeed Jack Gibbons as science adviser to President Bill Clinton and director of the White House's Office of Science and Technology Policy (OSTP).

The announcement of the appointment, which ends 18 months of sometimes fanciful speculation about who would succeed Gibbons, was made by Clinton during his address on 13 February to the annual meeting of the American Association for the Advancement of Science (AAAS) in Philadelphia. It was the first speech made by a sitting president at the meeting since Harry Truman spoke there 50 years ago.

Clinton also said that Rita Colwell, currently director of the biotechnology institute at the University of Maryland at College Park, will succeed Lane as director of the NSF. Colwell, whose main research interest is the study of marine microbes, was nominated last month to serve as Lane's deputy, and now becomes the first life scientist - as well as the first woman - to lead the NSF.

Speaking immediately after Clinton's announcement, Lane said he was "very honoured" to succeed Gibbons. Asked why he was ready to accept a job that is widely regarded as a lot of trouble, Lane said simply:

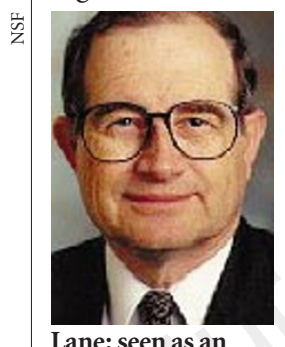

Lane: seen as an effective operator.
"I'm interested in the whole of the scientific enterprise, and the president asked me."

But he added that the offer of the post had not come directly from Clinton. "It was conveyed to me," he said. "I'd been talking to the vice-president, and of course today I got the opportunity to meet with the president. I'm hoping now to build on the work that Jack Gibbons has done."

The appointment has already triggered speculation about how the mild-mannered Lane will fare in the hot-house atmosphere ofClinton's White House. "It'll be interesting to see how he gets on," says one scientist who recently served under Gibbons at OSTP. "I wouldn't have thought it'd be his style, because he's basically a quiet guy."

But defenders of Lane, who worked as a physics professor and then provost of Rice University in Houston, Texas, before becoming director of the NSF in 1993, say that he has learned to operate effectively in Washington in the five years since then.

Lewis Branscomb, a former chairman of the National Science Board and now at Harvard University, said he thought Lane would do well. "If you look at how he's led NSF, he's been cautious, careful and skilful. He's made NSF's role clear to the Congress."

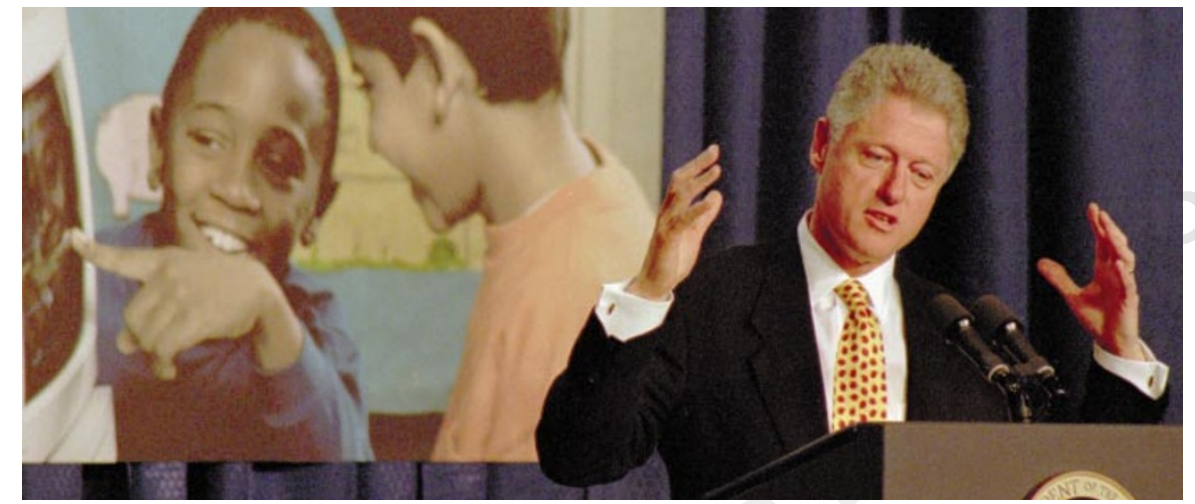

Science fan: President Clinton addresses the AAAS meeting, the first sitting president to do so in 50 years. In addition to announcing new appointments, he praised fusion and AIDS research.

Branscomb added that some of the earlier speculation that a "heavy hitter" such as John Deutch, the former deputy defence secretary, or Norman Augustine, the chief executive of Lockheed Martin, might take the OSTP post was "just ridiculous", as the job lacked the clout needed to attract such people.

More support for Lane came from Chuck Larson, director of the Industrial Research Institute. "It is the perfect match, under the conditions we have," he said. "We were looking for an industrial person, such as Norman Augustine, but it's tough to get someone like that. Neal has fought for NSF's budget, he's worked with the Congress, and he'll get on with the president."

Clinton's address to the AAAS was low key and repeated points made in his recent State of the Union address and in other recent speeches about science (see Nature 391, 521; 1998). The president, who is being relentlessly hounded over allegations of marital infidelity, looked tired, although he appeared to be reinvigorated as he mingled after the meeting with some of the 2,500 scientists and schoolchildren who came to hear him.

One man who was pleased to shake his hand was Dale Meade of the Princeton Plasma Physics Laboratory in New Jersey, as Clinton had endorsed the fusion programme in his speech, predicting that in 50 years' time "fusion and solar power may yield abundant energy". Clinton also praised progress in AIDS research: "If this progress continues, I believe we'll have an effective vaccine within a decade," he said.

Lane needs security clearance, as well as Senate confirmation, before he can take up the position, and this could take two or three months. Gibbons will leave the post on 15 March.

Colin Macilwain

\section{$\mathrm{NIH}$ peer-review revision panel is named}

[WASHINGTON] The US National Institutes of Health (NIH) last week announced the 15 members of a 'blue ribbon' panel charged with exhaustively reviewing - and making recommendations for changing - the structure of its peer-review system.

The panel will spend the next year studying the organization of some 100 study sections and deciding whether they reflect current science or have become anachronistic. It is expected to advise on whether a broad reconfiguration of sections is needed, or whether regular monitoring is sufficient to keep the composition and subject areas of sections up to date.
Prominent members of the Panel on Scientific Boundaries for Review include Bruce Alberts, the president of the National Academy of Sciences, Stuart Orkin of Harvard Medical School and David Botstein of the Stanford University School of Medicine. The chair of the panel will be appointed at its first meeting, which is unlikely to take place before April.

Alberts, who has chaired a study section, says that many of the study sections represent "ancient ways" of dividing up the field, and that some form of change is needed. He favours broader study sections that look for innovation, and would also like to see close scrutiny of ossified sections that may have become virtual entitlement programmes for their "regular clientele", while other sections in cuttingedge areas are overwhelmed with deserving applications.

Elvera Ehrenfeld, director of NIH's Center for Scientific Review, who appointed the panel as part of a broad reassessment of NIH's peer-review system, says she is open to all ideas that aim to keep peer review abreast of science. "The process needs to be driven by science, and not the other way around," she told the advisory panel to Harold Varmus, director of the $\mathrm{NH}$, in December. Meredith Wadman 